\title{
Reflection on the Rule of Law in China's Supervision Procedure
}

\author{
Wang Chao and Song Zhenyu* \\ College for Criminal Law Science \\ Beijing Normal University, China. \\ *Corresponding author's email: wangchao [AT] bnu.edu.cn
}

\begin{abstract}
Deepening the reform of the national supervision system is a major political system reform that is related to the overall situation and a major decision-making deployment to strengthen the self-supervision of the party and the state. Although the promulgation and implementation of the supervision law is objectively conducive to the party's centralized and unified leadership of anti-corruption work and the full coverage of public power supervision, from the perspective of the rule of law, there are many problems in the supervision procedure formulated by the supervision law, which need to be deeply reflected. These problems mainly include: the lack of operability and transparency in many details of the supervision procedure; the confusion between the implementation of inner-party laws and the implementation of national laws; the confusion between the investigation of duty-related violations and the investigation of duty-related crimes; the self-determination and implementation of investigation measures; the selfdetermination and self implementation of lien measures; the inability of lawyers to intervene in the supervision procedure; the lack of effective supervision by the supervision commissions.
\end{abstract}

Keywords---- reform of national supervision system; Supervision Law of the People's Republic of China; supervision procedure; reflection on the rule of law

\section{INTRODUCTION}

Although supervision system has been set up for a long time in China, the former supervision system is mainly administrative supervision, involving only the scope of functions and powers of the administrative field, and not involving other state organs and party organs. Since the 18th national congress of the CPC, the CPC Central Committee with comrade xi jinping as the core has made major strategic decisions to deepen the reform of the national supervision system in order to build a centralized, unified, authoritative and efficient national supervision system with full coverage of public power and improve the efficiency of anti-corruption. On November 12, 2013, the Third Plenary Session of the 18th Central Committee of the Communist Party of China adopted the "Decision of the CPC Central Committee on Several Major Issues of Comprehensively Deepening Reform", which clearly stated that the system of checks and oversight over the exercise of power should be strengthened, and the checks and oversight over the exercise of power by major leading cadres should be strengthened and improved. This decision started the deepening the reform of the national supervision system. On November 4, 2016, in order to promote the reform of the national supervision system, the general office of the Central Committee of the Communist Party of China printed and issued the "Pilot Plan for the Reform of the National Supervision System in Beijing, Shanxi Province and Zhejiang Province", and decided to set up supervision commissions at all levels in these three provinces and cities to carry out the pilot of the reform of the supervision system, so as to accumulate experience for the promotion of the supervision system throughout the country. The Plan emphasizes that the reform of the national supervision system is a major political reform concerning the overall situation and the top-level design of the national supervision system. The goal of deepening the reform of the national supervision system is to establish a national anti-corruption organization under the unified leadership of the party. On December 25, 2016, the 25th meeting of the Standing Committee of the 12th National People's Congress passed the "Decision on Carrying out the Pilot Work of National Supervision System Reform in Beijing, Shanxi Province and Zhejiang Province", and decided to set up supervision commissions in Beijing, Shanxi Province, Zhejiang Province and the counties, cities and municipal districts under its jurisdiction to exercise the supervision power, and to set up the supervision department (bureau) of the people's

* Wang Chao, Professor of the College for Criminal Law Science of Beijing Normal University; Song Zhenyu, a Ph.D. candidate of College for Criminal Law Science of Beijing Normal University. This article is the phased outcome of the 2017 National Social Science Fund Project: Research on Substantive Sanctions for Criminal Procedure Violations (No.17BFX182).

* Wang Chao, Professor of the College for Criminal Law Science of Beijing Normal University; Song Zhenyu, a Ph.D. candidate of College for Criminal Law Science of Beijing Normal University. This article is the phased outcome of the 2017 National Social Science Fund Project: Research on Substantive Sanctions for Criminal Procedure Violations (No.17BFX182). 
Government of the pilot area, integrating the relevant functions of the Corruption Prevention Bureau and the People's Procuratorate in investigating and punishing corruption and bribery, dereliction of duty and prevention of duty crimes into the Supervisory Commission. The above plans and decisions officially opened the prelude of deepening the reform of the national supervision system.

On October 18, 2017, General Secretary Xi Jinping made a work report at the nineteenth National Congress of the Communist Party of China, fully affirming the success of the state supervision system reform pilot, and making clear a major strategic decision to push the reform of the national supervisory system across the country. Therefore, the pilot work of the reform of the supervision system was pushed forward throughout the country, and the supervisory commissions at the national, provincial, municipal and county levels were established to work together with the party's discipline inspection organs, to achieve the full coverage of supervision over all public officials exercising public power; the National Supervision Law was formulated to give the supervision commissions the responsibility, authority and investigation means according to law, and replace the "two regulations" measures with lien.

On November 4, 2017, the Standing Committee of the 12th National People's Congress passed a resolution at its thirtieth meeting on the basis of summarizing the experience of the pilot work of the reform of the national supervision system, and decided to push forward the pilot work of the reform of the national supervision system throughout the country. On March 11, 2018, the first session of the 13th National People's Congress adopted the "Amendment to the Constitution of the People's Republic of China", which confirmed the achievements of the reform of the national supervision system, clarified the establishment and functions and powers of the National Supervision Commissions, and provided the constitutional basis for the further reform of the National Supervision Commissions and the formulation of the Supervision Law of the People's Republic of China. On March 17, 2018, the first session of the 13th National People's Congress deliberated and adopted the "Institutional Reform Plan of the State Council", which incorporated the Ministry of Supervision and the State Corruption Prevention Bureau into the newly established National Supervisory Commission, and no longer retained the Ministry of Supervision and the State Corruption Prevention Bureau. On March 20, 2018, the first session of the 13th National People's Congress voted and passed "Supervision Law of the People's Republic of China", making more systematic provisions on the establishment and responsibilities of supervisory organs, the jurisdiction of supervisory committee, supervisory authority, supervisory procedures, international cooperation against corruption, and supervision of supervisory organs and supervisors.

Deepening the reform of the state supervision system is a major political system reform made by the Party Central Committee with Comrade Xi Jinping as the core, and is a major decision-making arrangement for strengthening the selfmonitoring of the party and the state. At the first session of the 13th National People's Congress, Li Jianguo, vice chairman of the Standing Committee of the National People's Congress, pointed out on the explanation of Supervision Law of the People's Republic of China (Draft) that the formulation of supervision law is the practical need to provide strong legal guarantee for the anti-corruption struggle in the new situation, the innovative act to adhere to the organic unity of innerparty supervision and national supervision, and the strategic initiatives for the modernization of national governance system and governance capacity. General secretary Xi Jinping's important speech delivered during the eleventh collective learning of the nineteen Central Political Bureau also pointed out that the reform of state supervision system is conducive to the centralized and unified leadership of the party in anti-corruption work, and is conducive to the full coverage of public power supervision, and is conducive to address both symptoms and root causes and consolidating the results of the fight against corruption. Although the reform of the national supervision system is objectively conducive to the integration of anti-corruption resources, strengthening the party's centralized and unified leadership of anti-corruption work, building a centralized, unified, authoritative and efficient national supervision system with Chinese characteristics, and realizing the full coverage of all public officials exercising public power, we must carefully examine the supervision procedures established by the Supervision Law of the People's Republic of China from the perspective of modern rule of law. This is because, although modern countries under the rule of law never deny the necessity and importance of punishing corruption, its prerequisite must be to punish corruption through due process. Although according to the standards of due process, it is not necessarily able to ensure that the state punishes corruption accurately and effectively, and even sometimes leads to the result of indulgence in corruption, but the state punishes corruption through due process, regardless of the result, is acceptable and convincing. On the contrary, if the legitimacy of the procedure is not taken into account in order to effectively punish corruption, even if all corrupt elements are brought to justice, it may not be convincing, let alone that people will express acceptance from the heart. In view of this, this paper intends to briefly reflect on the main defects of China's supervision procedure from the perspective of modern rule of law, so that the legislature can improve the degree of legalization of supervision procedure by amending the supervision law in the future.

\section{THE SUPERVISION PROCEDURE LACKS OPERABILITY AND TRANSPARENCY IN MANY} DETAILS

Although corruption has very serious harmful consequences, it does not mean that the Commission for Discipline Inspection or the Supervisory Commission can do whatever it wants when investigating and handling corruption cases and punishing corrupt elements, without being bound by any laws or norms. This is because, in the context of the overall rule of law, although the Commission for Discipline Inspection or the supervisory committee has the right to investigate and deal with corruption cases, they must strictly abide by the procedures stipulated by the party's laws and regulations and the 
state's laws in the process of investigating and dealing with corruption cases, and correctly exercise the anti-corruption power given by the party and the state, without violating the basic requirements of the rule of law in the society due to the serious consequences of corruption. For this reason, the CPC Central Committee with Comrade Xi Jinping as its core has repeatedly stressed the use of the thinking way and style of rule of law in developing a clean and honest government and fighting against corruption.

Obviously, the logical premise of using the rule of law to fight against corruption is relatively complete anti-corruption legislation. In particular, the anti-corruption laws formulated by the legislature must be clear, specific and operable. Although the Supervision Law of the People's Republic of China has comprehensively and systematically stipulated a series of problems, such as supervision responsibility, supervision authority, supervision scope, supervision jurisdiction, supervision procedure, supervision and inspection, etc., based on theoretical research, legislative technology and other reasons, the supervision procedure stipulated in the Supervision Law of China is too principled, rough, vague and lack of operability and transparency in many details, and then affect the implementation of the supervision law. For example, according to the provisions of Article 17 of the supervision law, the conditions for subordinate supervisory organs to report to superior supervisory organs for jurisdiction are that the original supervisory organ thought that the supervisory matters under its jurisdiction were significant and complex, but the article did not further define what was significant and complex; although paragraph 2 of Article 33 of the Supervision Law stipulates that the collection, fixation, examination and application of evidence by supervisory organs should be consistent with the requirements and standards of evidence in criminal trials, the current law lacks further provisions on what the requirements and standards of evidence in criminal trials are; according to article 37 and article 38 of the Supervision Law, the disposal of problem clues needs to go through the examination and approval procedures, but the current supervision law has no further provisions on how to go through the examination and approval procedures; and so on.

Although in order to make up for the defects in legislation, the Central Commission for Discipline Inspection and the State Supervision Commission jointly issued several documents, such as the "Regulations on the Supervision of Law Enforcement by the Supervisory Organs", the "Measures for the Work of Special Inspectors of the National Supervision Commission" and the "Regulations on the Jurisdiction of the National Supervision Commission (Trial)", there are also obvious defects in this practice. On the one hand, when the Central Commission for Discipline Inspection and the State Supervision Commission jointly issue documents related to the supervision law, it is difficult to determine the nature of the documents. It is because that according to China's current legal theory and legal system, the documents jointly issued by the Central Discipline Inspection Commission of the Party and the State Organs of Supervision Commissions are not the legislative interpretations made by the legislature, or the judicial interpretations made by the Supreme People's Court and the Supreme People's Procuratorate. It does not belong to administrative regulations made by government agencies, and is different from the party's internal regulations formulated by the Central Committee of the Communist Party of China. On the other hand, although the "Regulations on the Supervision of Law Enforcement by the Supervisory Organs" jointly formulated by the Central Commission for Discipline Inspection and the State Supervision Commission on July 15, 2019 objectively contribute to the better implementation of the supervision law, this provision is an internal document. So far, the Central Commission for Discipline Inspection and the National Supervision Commission have not publicly issued the entire contents of the regulation. From the perspective of comprehensively governing the country according to law, "Regulations on the Supervision of Law Enforcement by the Supervisory Organs" as the implementation methods and detailed rules of the supervisory law, should have been publicly solicited for opinions and published, rather than being issued and implemented only within the Discipline Inspection Commission and the Supervisory Commission in the form of secret documents or internal documents.

\section{CONFUSION BETWEEN THE IMPLEMENTATION OF INNER-PARTY LAWS AND REGULATIONS AND THE IMPLEMENTATION OF NATIONAL LAWS}

Theoretically, the laws and regulations within the party and the national laws are not only different from each other, but also related to each other. Although the laws and regulations within the party and the state laws are both behavioral norms formulated through certain procedures, they are two concepts with different natures and cannot be confused with each other. Generally speaking, the inner-party laws and regulations are the general term of the inner-party rules and regulations formulated by the relevant organizations of the party to regulate the work, activities and behaviors of party members. The party constitution is the most fundamental inner-party laws and regulations, and the basis for formulating other inner-party laws and regulations. The national law is formulated or recognized by the state, and enforced by the state to ensure the implementation of the code of conduct, which has a general binding force on all members of society. The constitution is the fundamental law of the country and the basis and foundation for other laws. National laws include the constitution, laws, administrative regulations, local regulations, autonomous regulations and single regulations. Although the concept of inner-party laws and regulations also contains the words of "laws and regulations", inner-party laws and regulations have specific formulation subjects, adjustment scope and application objects, and do not belong to the scope of national laws. There are obvious differences between the inner-party laws and the national laws in many aspects, such as the main body, the procedure, the object of adjustment, the scope of application and the way of implementation. The difference between the laws and regulations within the party and the national laws determines that the implementation of discipline and the implementation of laws are two completely different concepts. In the past, in order to fully reflect the 
boundary between the national law and the party discipline, China adopted a decentralized anti-corruption model, that is, different anti-corruption organizations implement the party regulations and the national laws within their respective functions and powers. Further, the Communist Party of China has set up discipline inspection committees within the party to investigate and punish party members for their violations of party discipline. According to the constitution and laws, the Chinese government has set up administrative supervisory organs and people's procuratorates, under which administrative supervisory organs investigate and punish administrative organs for their acts of violating administrative discipline, while the people's procuratorates conduct criminal investigations for their acts of duty crimes. If a party member under investigation by the commission for discipline inspection only commits disciplinary violations and is not involved in an official crime, the party member will not be transferred to the criminal justice organ for handling. However, if the party member is suspected of committing an official crime, he or she will be transferred to a people's procuratorate for criminal investigation.

Although the establishment of decentralized anti-corruption institutions fully reflects the boundary between the implementation of laws and regulations within the party and the implementation of national laws, this mode will objectively affect the efficiency of anti-corruption. It is in this context that, in order to solve the shortcomings of decentralized anticorruption institutions in terms of overlapping institutions, decentralization of power, high cost of anti-corruption and low efficiency of anti-corruption, and strengthen the party's centralized and unified leadership over anti-corruption institutions, China has set up supervision measures for all public officials through deepening the reform of the discipline inspection system. In addition, the newly established commission and the original commission can be co-located. the Disciplinary Inspection Committee and the Supervisory Committee concentrate on the two anti-corruption functions of disciplinary inspection and state inspection. Although this kind of anti-corruption organization setting mode helps to achieve the full coverage of anti-corruption and strengthen the party's centralized and unified leadership of anti-corruption, the Discipline Inspection Committee and Supervision Commission after the reform are also prone to the situation that the implementation of the party's laws and regulations is not separated from the implementation of the country's laws because the anticorruption power is too centralized. First of all, in the case of the joint office of the Disciplinary Inspection Committee and the Supervision Commission, whether it is discipline or law enforcement, whether the executive body is a disciplinary inspection committee or a supervisory committee is unclear. Secondly, in the case that the Disciplinary Inspection Committee and the Supervisory Committee are both disciplined and enforced, there may be situations in which discipline and law enforcement are confused or mutually exclusive, that is, disciplinary action is used instead of criminal sanctions, or criminal sanctions are used instead of disciplinary action. Finally, in the case of the joint office of Discipline Inspection Committee and the Supervision Commission, the discipline inspection activities conducted by the Discipline Inspection Committee according to the laws and regulations of the party may be combined with the investigation activities conducted by the Supervision Commission according to the national laws, so as to mix the two anti-corruption functions and procedures of different natures into one, thus affecting the legalization or transparency of anti-corruption.

\section{INVESTIGATION OF DUTY VIOLATION IS MIXED WITH INVESTIGATION OD DUTY} CRIME

Before the enactment of Supervision Law, the biggest feature of the establishment of anti-corruption institutions in China was that specialized anti-corruption institutions, such as the Disciplinary Inspection Committee, the administrative supervision organ, the People's Procuratorate, the Corruption Prevention Bureau and so on, carried out anti-corruption work respectively for corruption acts of different natures according to different functions and powers and procedures. In this case, the anti-corruption agencies have significant differences in investigating and dealing with the disciplinary violations, illegal acts and criminal acts of public officials, which cannot be confused with each other. Although this kind of anti-corruption organization has made remarkable achievements in the past anti-corruption practice, this mode is more and more difficult to meet the needs of China's in-depth construction of party conduct and clean government and anticorruption struggle because the anti-corruption power is too decentralized, the anti-corruption cost is too high and the anticorruption efficiency is too low. Moreover, the anti-corruption practice of many countries in the world has proved that the establishment of a unified and specialized anti-corruption agency has become an important way and successful experience for many countries to increase anti-corruption efforts and improve anti-corruption efficiency. It is against this background that China enacted the supervision law in 2018, abolishing the anti-corruption functions of administrative supervision organs and People's Procuratorates, and the newly established Supervision Commission uniformly investigates and deals with all the officials' duty violations and duty crimes.

Although it is helpful to improve the efficiency of anti-corruption to investigate the duty-related violations and crimes by the Supervision Commission, this practice has obvious disadvantages because of the incongruity between the Supervision Law and the Criminal Procedure Law. According to article 39 of the Supervision Law, supervisory commissions can file cases of both duty violations and duty crimes. According to article 19 of the Criminal Procedure Law, criminal judicial organs can only file cases for criminal acts. In criminal proceedings, criminal filing not only means the formal beginning of criminal proceedings, but also means that criminal judicial organs can take compulsory measures and have compulsory investigation measures against criminal suspects. If there is no criminal case filing, the criminal judicial organ can neither restrict or deprive any citizen of personal freedom, nor take compulsory investigation measures against any citizen. However, according to the provisions of China's Supervision Law, as long as the Supervisory Commission 
files a case, it can take all measures of investigation and detention against the person under investigation without distinguishing between the illegal act of duty and the crime of duty. In particular, it is worth noting that the Supervisory Commission has the right not only to file a case against a public official suspected of duty-related crimes and then take investigation measures and retention measures, but also to file a case against a non-public official related to duty-related crimes and then take investigation measures and retention measures. In criminal proceedings, in order to file a case for non-public officials and then take investigative measures and enforcement measures, it must be based on the premise that non-public officials are suspected of committing crimes. The above not only reflects the inconsistency between the Supervision Law and the Criminal Procedure Law, but also reflects the inconsistency between non-public officials in the supervision process and the criminal justice process. This not only undermines the unity of the rule of law, but also undermines the principle of equality before the law.

\section{SELF-DETERMINATION AND SELF-EXECUTION OD INVESTIGATION MEASURES}

In the modern country of the rule of law, in order to guarantee the legitimate rights and interests of the criminal suspect, and prevent the investigation organ from abusing their powers of investigation, the writ doctrine is generally applied, that is, a neutral court or judge carries out judicial review and judicial control over the investigation conducted by the investigation organ. Further, in addition to an emergency situation, if the investigation organ is prepared to take a coercive investigation means such as a search, seizure, seizure, freezing, etc., or a secret detection means, such as search, detention, seizure, freezing, etc., or technical or secret means of investigation, such as monitoring, surveillance, etc., it shall obtain the writ of a neutral third party, that is, the court. Only after obtaining the writ issued by the court or the judge can the investigation organ adopt the corresponding coercive investigation means or technical and secret investigation means to the criminal suspect or the property involved in the case. Writ doctrine is a principle of rule of law widely adopted in criminal proceedings in western countries ruled by law. The basic purpose of writ doctrine is to enable the judicial organ as a third party to examine the reasons and necessity of coercive investigation measures and to make a fair judgment in order to prevent the abuse of coercive investigation techniques and thus to protect the basic human rights of citizens. If that investigative organ is in breach of the writ doctrine, the investigation act of the investigative organ will be regarded as the act of illegal investigation. According to the exclusion rule of illegal evidence, the evidence obtained by the investigation organ through the illegal investigation act should be excluded, which can not be used as the basis for the court to judge the defendant guilty.

In accordance with the provisions of the Supervision Law of the People's Republic of China on investigation measures, in the course of investigating cases of duty violation or duty crime, either taking less coercive investigation measures (such as routine interrogation, inquiry, query, etc.), or more coercive investigation measures (such as search, detention, seizure, freezing, etc.), or technical investigation measures with strong secrecy shall be decided and implemented by the supervisory organs in accordance with internal procedures, without the need of examination and permission of any neutral third party. Moreover, in the absence of judicial review and judicial control of the neutral court in the investigation activities of the supervisory organs, in addition to that fact that the person under investigation is unable to employ a lawyer to provide legal assistance, the investigation activities of the supervisory organs shall be carried out entirely by themselves without any restriction from the outside world. In this case, in the investigation activities of the supervisory organs, the persons under investigation have to face the mighty supervisory organs directly because of their isolated status. Based on the conflict of interests between the supervisory organs and the persons under investigation, the legitimate rights and interests of the isolated person under investigation in the investigation activities are vulnerable to infringement by the supervisory organs.

\section{SELF-DETERMINATION AND SELF-EXECUTION OF DETENTION MEASURES}

In a modern country ruled by law, based on the basic spirit of the doctrine of the presumption of innocence, anyone should be presumed innocent until he is convicted by the court in accordance with the procedure prescribed by law. In criminal proceedings, even a suspect should be treated as an innocent person, and enjoy the legal treatment of innocence in the status of litigation. In order to carry out the basic spirit of the doctrine of the presumption of innocence and prevent arbitrary or excessive restriction or deprivation of the personal freedom of the criminal suspect, the criminal justice organ shall be obliged to treat the suspect like the ordinary person, in particular, to avoid taking detention coercive measures to deprived the criminal suspect of personal freedom. Even if it is necessary for criminal judicial organs to take mandatory measures against criminal suspects in order to prevent them from evading trial or obstructing the normal conduct of criminal proceedings, the duration of their detention should not be too long. For this reason, in order to prevent arbitrary deprivation of the personal freedom of the criminal suspect by the investigative organ, the modern country under the rule of law not only apply the bail system generally, but also impose a more strict judicial review procedure for detention measures. That is, only in the case of a neutral judge issuing a warrant, the investigative organ can arrest and detain the criminal suspect.

Although the Supervision Law of the people's Republic of China does not provide for criminal detention or arrest measures, it stipulates basically the same detention measures as criminal detention or arrest measures. In the light of the provisions of the Supervision Law and the Criminal Procedure Law, although there are obvious differences between detention and criminal detention and arrest in terms of applicable conditions and procedures, they will all lead to the result of a suspect in the custody as far as the legal consequences are concerned. It is precisely because they all deprive criminal suspects of their personal freedom, so the Supervision Law and Criminal Law stipulate that if a criminal suspect is 
eventually sentenced to control, criminal detention or fixed-term imprisonment in accordance with the law, then for a criminal suspect who is detained or retained before the execution of the sentence, one day of detention or one day of custody is a discount of two days of control, a discount of one day criminal detention and one day of imprisonment. Despite the same legal consequences of the deprivation of liberty as a result of the detention, criminal detention and arrest, the provisions of the Supervision Law on the detention procedure are relatively loose. First, although supervisory organs need to go through relatively strict procedures for the approval of detention measures, the application of the detention measures does not need to go through the examination and approval of neutral judges in advance. In accordance with the provisions of Article 43, paragraph 1, of the Supervision Law of the People's Republic of China, adoption of detention measure by a supervisory organ shall be decided upon collective research of leaders of the supervisory organ or be reported to the supervisory organ at the immediately higher level for approval. Secondly, in accordance with the provisions of Article 43, paragraph 2, of the Supervision Law of the People's Republic of China, although detention shall not exceed three months, under particular circumstances, the supervisory organ may extend the detention once for not more than three months after reporting to the supervisory organ at the immediately higher level for approval. Thirdly, in accordance with the provisions of Article 22 and Article 43 of the Supervision Law of the People's Republic of China, after deciding to take detention measures, the supervisory organ does not submit the detention measures to other relatively neutral organs or special organs for implementation, but personally detain the persons under investigation in a specific place set up by the supervisory organs themselves. Although it is up to the supervisory organs to decide and implement detention measures on their own to improve the efficiency of anti-corruption, this overemphasis on efficiency not only violates the judicial writ generally observed by modern countries ruled by law, but also easily damages the legitimate rights and interests of the person under investigation, making the person under investigation completely a tool for collecting evidence by the supervisory organ.

\section{LAWYERS ARE UNABLE TO INTERVENE IN THE SUPERVISION PROCEDURES}

In theory, it is of great significance to rule by law for lawyers to provide legal assistance to person under investigations suspected of duty crimes. First of all, the modern legal system is becoming more and more complex. Even if the person under investigations suspected of duty crime has a higher comprehensive quality or even professional legal knowledge, they also need the help of a lawyer objectively. Especially in the case of restriction of personal freedom caused by detention measures, lawyers are needed to give some help. Second, in the process of investigation, since the supervisory commission and the person under investigation have a direct interest, the two are prone to fierce conflict. In the case of the Commission being very mighty and the person under investigation being weak, if there is no lawyer to give some help, then the legitimate rights and interests of the person under investigation will be vulnerable to infringement by the Supervisory Commission. Thirdly, compared with prosecution activities and trial activities, the investigation activities of the supervisory commission are as aggressive and mandatory as the investigation activities of the investigative organizations, which determines that the legitimate rights and interests of the person under investigation are highly vulnerable to infringement in the investigation activities. In order to successfully complete the investigation tasks entrusted to it by the State and the law, the supervisory commission has a great possibility of illegal evidence collection in the course of the investigation. Therefore, in order to fully protect the legitimate rights and interests of the person under investigation and restrict the investigation activities of the Supervisory Commission, lawyers are needed to intervene in the investigation activities of the Supervisory Commission. Finally, according to the provisions of the Criminal Procedure Law of the people's Republic of China, as long as they are suspected of crime, they have the right to hire defense lawyers to provide legal assistance for them in the investigation stage. Public officials under investigation by the Supervisory Commission should not be deprived of the right to hire a lawyer just because they are suspected of committing duty-related crimes. Otherwise, it will violate the modern rule of law principle that everyone is equal before the law.

In spite of the fact that the person under investigation suspected of having a duty-related crime objectively needs lawyers to provide legal assistance, according to the provisions of the current supervision law on supervision procedures, when the supervisory commission is investigating the person for suspected duty-related crimes, the person under investigation has no right to hire a lawyer to provide legal assistance, but can only defend himself in front of the case handling personnel without the participation of the outside world. In accordance with the provisions of Article 44, paragraph 1, of the Supervision Law of the people's Republic of China, after the detention measure is taken against the person under investigation, the entity where the detained person works and his or her family member shall be notified. However, the supervisory commission does not have the obligation to inform the person under investigation to hire a lawyer. In fact, even if that person to be investigated has been taken the detention measure to lose personal freedom, Article 44, paragraph 2, of the Supervision Law of the People's Republic of China only stipulates that the supervisory organ shall guarantee the food, drink, rest and security of the detained person, and provide medical services. The person under investigation, in addition to his own excuse, was not empowered with the right to engage a lawyer to provide legal assistance to him. In this case, throughout the investigation, the person under investigation can only face a strong supervisory commission on his own. Based on the naked conflict of interest between the supervisory commission and the investigated person, and the person under investigation is also obliged to confess truthfully when he or she is deprived of his or her liberty, the investigated person has almost completely become a source of tools and evidence to punish corruption in front of a strong supervisory organ, and is in the state of being trampled upon at will and isolated. 


\section{LACK OF EFFECTIVE SUPERVISION ON THE SUPERVISORY COMMISSIONS}

After the reform of the China's supervision system, the Supervisory Commissions have no doubt of strong power in the area of anti-corruption. From the perspective of the supervisory objects, the Supervisory Commissions could take supervision on all public officials to truly realize full coverage of all public officials and the full coverage of anticorruption.In the case of the supervisory methods, the Commission has the broad powers vested in the Supervision Law.In particular, when the Commission takes investigation and detention measures, it only needs to go through the examination and approval process within the supervisory system, and does not need to go through the judicial review and judicial control of the neutral court.From the perspective of supervisory process, the investigation activities conducted by Supervisory Commission have a strong confidentiality, which can not be intervened by the outside world.Even the person under investigation cannot hire a lawyer to provide legal assistance.In the light of the supervisory results, the Commission may not only hold the liability for disciplinary offence of the person under investigation, but also hold the person under investigation's job-breaking liabilities, and also hold the person under investigation's duty-related crime.It is because of the super power of the supervisory commission that the theoretical circle, especially the criminal procedure law circle, is concerned that the supervisory commission may abuse its anti-corruption power because of its excessive power.

Perhaps in order to solve the problem of the "Who will supervise the supervisor?" and to prevent the Commission from abusing its strong anti-corruption powers, the Supervision Law of the people's Republic of China clearly stipulates the supervision of supervisory organs and supervisors.According to Articles 53 to 61 of the Supervision Law of the people's Republic of China, at present, the supervision of supervisory organs and personnel mainly includes the following methods: (1)the supervision of people's congresses at the corresponding level and their standing committees, such as listening to the special work reports of supervisory commissions,organizing law enforcement inspections, raising questions or inquiring about issues in the supervision work, and so on;(2)Supervisory organs shall disclose the information on the supervision work in accordance with the law, and accept democratic supervision, social supervision and public opinion supervision; (3)Supervisory organs shall, by such means as establishing special internal supervisory bodies, strengthen the supervision of supervisors' performance of their functions and compliance with laws.If a supervisor makes inquiries about the details of a case, intervenes in the handling of a case or solicits favor on behalf of any person, the supervisor who handles supervision matters shall report it in a timely manner and register relevant information for recordation; (4)Building a loyal, clean and responsible supervisory team, and strengthening the supervision of the supervisory personnel; (5)When there is a violation of laws and regulations, such as failing to remove detention upon expiration of the statutory period, and the violation of the lawful rights and interests of the person investigated, the person under investigation and his or her close relatives have the right to file an appeal with the supervisory organ; (6)Where, after the completion of investigation, it is discovered that the basis for docketing the case is insufficient or erroneous, there is any major mistake in the handling of the case, or the supervisor has any serious violation, the responsible leader and directly liable persons shall be held liable. In order to further promote the supervision organs to accept democratic supervision, social supervision and public opinion supervision in accordance with the law, the Central Commission for Discipline Inspection of the Communist Party of China and the National Supervisory Commission jointly issued the "Measures for the Work of Special Supervisors of the National Supervision Commission" on 24 August 2018, which decided to employ the Special Ombudsman to monitor the performance of the discipline inspection and supervision organ and its staff, and put forward the opinions and suggestions to strengthen and improve the work of the discipline inspection and supervision.

Although the current supervision has paid attention to the problem of "who will supervise the supervisors", and many measures have been taken to strengthen the supervision of the supervisory organs and supervisors, these supervision measures have obvious limitations and it is difficult to play their due supervisory role. First of all, from the current provisions of the Supervision Law, the supervisory organs and supervisors have a strong unilateral nature and confidentiality when investigating official illegal acts or official crimes, so it is difficult for the outside world to deeply understand the whole process of the investigation activities. This may lead to the supervision of the National people's Congress, social supervision, democratic supervision, supervision by public opinion, supervision of special ombudsmen, etc., become a mere formality. Secondly, although the person under investigation and his or her close relatives have the right to file an appeal with the supervisory organ, it is difficult for the person under investigation and his or her close relatives to exercise their right of complaint effectively if the person under investigation and his or her close relatives are unable to participate fully in the investigation and, in addition, the person under investigation is unable to employ a lawyer to provide legal assistance to him or her. Moreover, if the person under investigation and his or her close relatives can only lodge complaints within the supervisory system, it is difficult to ensure that the supervisory organ will handle the complaints of the person under investigation and his or her close relatives impartially. Finally, although the Supervision Law provides for a wide variety of supervision methods, the current supervision system is essentially subject to post supervision and soft supervision. However, whether it is post supervision or soft supervision, it is very difficult to form an effective restriction on the powerful supervisory organs and the supervisory personnel.

\section{CONCLUSION}

Since the $18^{\text {th }}$ National Congress of Communist Party of China, the Central Party Committee, which takes Comrade $\mathrm{Xi}$ Jinping as the core, has made major strategic decision-making deployment to deepen the reform of the national supervision system, thus becoming a fundamental guide for China's anti-corruption work in the new historical period. The 
deepening of the national supervision system reform is a major political system reform that affecting the overall situation, the actual need of the Chinese Communist Party to carry out the anti-corruption struggle, and a major institutional innovation in the field of anti-corruption in China. However, from the point of view of using the thinking and the way of the rule of law to carry out anti-corruption work, there are a series of problems in the Supervision Law of the People's Republic of China that are not consistent with the modern concept of the rule of law and urgently need to be further reformed.

\section{REFERENCES}

1. Jeremy Pope, Anti-Corruption Strategy-Report from Transparency International, translated by Wang Miaoyang, Shanghai Translation Publishing House,2000 edition.

2.Ji Zhengju, The Road to Integrity _ Experience and Lessons in Anti-Corruption at Home and Abroad,Central Compilation and Translation Press,2005 edition.

3. Yan Qunli, An Investigation and Study on the Construction of Integrity and Anti-Corruption at Home and Abroad, China Fangzheng Press, 2007 edition.

4.OECD, Specialised Anti-Corruption Institutions : Review of Models, OECD Publishing, 2008.

5. Michael Johnston, Syndromes of Corruption: Wealth, Power and Democracy, translated by Yuan Jianhua, Shanghai People's Publishing House,2009 edition.

6. Chen Hui, The 90-years of Combating Corruption and Upholding Integrity of Communist Party of China, Shanghai People's Publishing House 2011 edition.

7.OECD, Specialised Anti-Corruption Institutions : Review of Models (Second Edition), OECD Publishing, 2013.

8. Li Qiufang, Sun Zhuangzhi, International Comparative Study on Institutional Mechanisms against Corruption, China Social Science Press, 2015 edition.

9. Xi Jinping, Excerpt from Xi Jinping's Discussion on Promoting Ethical party and Government and the Struggle against Corruption, Central Compilation and Translation Press, 2017 edition.

10. Qin Qiang, Supervision of Power: the Cultural Inheritance and Institutional Innovation of the National Supervisory Commission, People's Daily Publishing House, 2017 edition.

11. Sun Zhiyong, Strategy to Curb Corruption: Ten Lectures on Anti-corruption Theories with Chinese Characteristics since the 18th National Congress of the CPC (revised version), China Fangzheng Press, 2017 edition.

12.Jiang Guohua, Research on National Supervision Legislation, China University of Political Science and Law Press,2018 edition.

13.Ren Jianming,The Course of Anti-corruption in the New Era of China, Foreign Languages Press, 2018 edition.

14. Shao Jingjun, Liu Jincheng, Ed., The Innovation and Development of the Anti-Corruption Theory of the Chinese Communist Party in the New Era, China Fangzheng Press, 2018 edition.

15. Wu Jianxiong and Liao Yongan, Ed., Anti-corruption: The Connection between Supervision and Judicature, China Procuratorial Press, 2019 edition. 